\title{
Sectoral Balances And Stock-Flow Consistent Models
}

\author{
Jan Jonáš \\ Masaryk University, Brno, Czech Republic
}

Ondřej Komínek

Masaryk University, Brno, Czech Republic

\begin{abstract}
The European banking and sovereign debt crisis has revealed severe financial imbalances among countries and institutional sectors. In reaction, economic policy and theory has focused on the role of finance in mitigating economic imbalances and finding ways to deal with them. Policy makers launched data gap initiatives to enhance economic and financial statistics, an important pillar of these initiatives being the integrated framework of the System of National Accounts, unifying product, income, capital, and financial accounts. In this framework, there are elaborated Stock-Flow Consistent models that model any interconnections of institutional sectors, in both real and financial aspects, in a consistent way. This article aims to illustrate the principles and possibilities of Stock Flow Consistent models and their relation to the System of National Acounts. To accomplish this, we construct a simplified Stock Flow Consistent model applied to the sectoral (im)balances between the private, government, and foreign sectors, which were a notable feature of the recent European crisis.
\end{abstract}

JEL Classifications: B50, C69, E12

Keywords: Stock-Flow Consistent Models, System of National Accounts, Financial Accounts, ESA 2010, Euro Crisis

\footnotetext{
*Corresponding Author: Jan Jonáš; Department of Economics, Faculty of Economics and Administration, Masaryk University, Brno, Lipová 41a, 60200 Brno, Czech Republic, tel.: +420 54949 4534, Fax: +420 54949 1720, e-mail: jjonas@mail.muni.cz

Co-author: Ondřej Komínek; Department of Economics, Faculty of Economics and Administration, Masaryk University, Brno, Lipová 41a, 60200 Brno, Czech Republic, tel.: +420 54949 1710, Fax: +420 54949 1720,e-mail: 128490@mail.muni.cz 


\section{Introduction}

When the first signs of a major financial crisis appeared in the euro area, no one foresaw how far-reaching the consequences would be for the entire economy. After problems arose with the questionable value of securitized products, which affected the balance sheets of the banking sector, the contagion spread into the wider economy. The concurrent recession with rising unemployment stimulated further doubts about the sustainability of previously accumulated debts of households and non-financial corporations. Furthermore, the decline of tax receipts, the growth in government expenditure, and the expected restructuring costs of the insolvent banking institutions, shifted investors' attention towards the debt sustainability of individual euro area member states.

Naturally, economists and policy makers have questioned what happened and why the financial crisis had such a deep impact on the real economy. The major macroeconomic themes have been whether to restore growth by austerity or stimulus, the problematic financial position of European banks, the problematic vicious circle between unhealthy banks holding government debt and indebted states responsible for the banking stabilization stabilization (Reichlin, 2014), the balance of payment imbalances between core and periphery countries, and the deficiency in incomplete euro area integration, where the monetary union was formed without banking and fiscal union, as described by Blankenburg et al. (2013), De Grauwe (2013), Gros (2013), and Cesaratto (2017).

Generally viewed, all of the research has focused on particular sectoral balance sheet positions and how these are interrelated in real and financial terms. In this respect, accounting provides the key to the understanding of the crisis. This fact set off actions to improve the available accounting data for the purpose of a more profound economic analysis, improved monetary policy, and financial stability. The enhancement of statistical data especially concerned more specific and granular data for economic sectors and instruments, from-whom-to-whom data depicting mutual interconnections among sectors via specific instruments.

In statistics, this issue is captured mainly by improvements in financial accounts that provide an accounting framework enabling the monitoring of financial assets and liabilities for particular sectors in the economy. Furthermore, financial accounts are a naturally inherent part of the System of National Accounts (SNA) and therefore pose an important extension of non-financial accounts. These systemic aspects present important 
advantages due to their consistent integration of financial and non-financial aspects of the economy.

The crisis has also set off endeavors to enhance macroeconomic models in order to incorporate the financial sector, which was central to the crisis, and to make the vast bulk of the SNA data tractable. The pre-crisis macro models that were mainly utilized, such as real business cycle or dynamic stochastic general equilibrium models, are grounded in the classical dichotomy between the real and financial sectors. The main focus has been on the real analysis, while the monetary and financial aspects of the economy have been rather neglected. Although there have been attempts to enrich these models, like considering considering financial frictions, their methodological backgrounds have prevented them from meaningfully incorporating finance, and their uses have therefore been questioned, as argued by Bezemer (2016). However, the interesting solutions to building a model of complex economic reality that would incorporate the financial realm in a profound way have arisen from the accounting approaches to macroeconomics.

Financial accounts are mostly utilized in economic research for descriptions or analyses of some subpart of the financial system. The construction of macroeconomic models using this framework is rare. One line of research utilizing financial accounts in macroeconomic modeling is Stock-Flow Consistent (SFC) models, which originated and developed in the post-Keynesian economic tradition. Post-Keynesians put great emphasis on the role of money and finance in modern economies. For this reason, financial accounts appeal to them, and they have been able to interconnect these ingeniously with specific behavioral components into robust macroeconomic models. Moreover, financial statistics provide a rich source of data for these models.

In this article, we focus on the topic of euro area sectoral (im)balances from the perspective of a three-sector economy. This offers the advantage of introducing one of the fundamental building blocks of SFC modeling at the same time. Our ambition is not to contribute to the vast literature on the euro area crisis by some overlooked detail or a new interpretation. We rather intend to use the familiar context of this crisis to stylize the principles and possibilities of SFC modeling.

The aim of this article is twofold. First, we provide an explanation of the particular relationship between the SNA and financial accounts and SFC models. To our knowledge, this relationship has not been explored in detail in the literature before, and we consider this to be the main contribution of the article. Second, we present an illustrative and simplified theoretical SFC model for an open economy with three sectors to explain the fundamental principles of such models. For this purpose and in order to provide 
a context for the model, we focus on the topic of sectoral imbalances between the domestic private sector, the government sector, and the rest of the world that have been revealed during the recent financial crisis in the euro area. We provide a mathematical derivation of the SFC model using macroeconomic identities and behavioral equations. Focusing on the sectoral accounting relations of these sectors, the model reveals a deeper understanding of the interdependencies among sectors that played a role in the crisis.

The structure of the article is as follows: we begin with an introduction to the accounting approach to economic modeling, together with a presentation of the logic behind financial accounting. Importantly, the relation between product, income, capital, and financial accounts is illustrated. In the second part, we stylize the three-sector economy with its accounting relations, using the context of the recent financial crisis in the euro area and the related sectoral imbalances. The third part gives a general overview of SFC modeling and its history, working logic, and main areas of application. The fourth part of the article then illustrates the fundamental principles of SFC modeling in the case of an SFC model of a three-sector economy and provides some policy implications. Throughout the article, there is an emphasis on the connection between SFC models and financial accounts as provided by the methodology of European System of National and Regional Accounts known as European Space Agency (ESA) 2010.

\section{The Accounting Approach}

The period before the financial crisis has been designated as the Great Moderation, since the volatility of the business cycle was reduced. This was accompanied by low unemployment and inflation. Part of the economic profession held the view that the previously unstable economy was successfully stabilized. However, behind this seeming stability, financial imbalances were building up that eventually led to the economic crisis. Prevailing mainstream models were not able to forecast this scenario, since their focus was on real economic processes. As a reaction to this crisis, there arose an effort to enrich the financial variables available for macroeconomic analysis, described by Borio (2014).

One line of these concerns is grounded in the financial accounting framework. As Bezemer (2010) argues, economists utilizing accounting approaches that encompass financial balances were successful in spotting the signs of financial instability in advance 
and called attention to the unsustainability of previous economic growth, for example, a precise projection by Godley (1999b). These financial accounts rose in popularity after the crisis, especially in central banks where they find manifold usages. Bê Duc (2009) and Winkler (2010). Winkler (2014a, 2014b) presents a collection of many recent theoretical and applied studies utilizing financial accounts. The various applications include research into SFC models.

Generally defined, financial accounts are an integrated statistical system that reports the financial linkages in the economy, segmented by institutional sectors and financial instruments. The institutional sectors are classified primarily on a territorial basis between residents or total economy (S.1 code, ESA 2010) and the rest of the world (S.2). The total economy is then divided into several subsectors according to their main economic function and type of activity. The division consists of non-financial corporations (S.11), financial corporations (S.12), general government (S.13), households (S.14), and non-profit institutions serving households (S.15). These segmentations can be further granulated into subsectors. The financial instruments are classified mainly by their liquidity and legal characteristics.

For any sector, financial accounts capture the outstanding balances of financial assets and liabilities, i.e., stocks, as well as financial transactions or flows. The stocks are monitored on opening and closing balance sheets constructed for a specific time. The flows are recorded by three flow accounts, these being the financial transactions account, the revaluation account, and the other changes in assets account. The flow accounts capture the transition between the opening and closing balance sheets.

Financial accounts are a part of the larger system of national accounts formed also by product, income, and capital accounts. This is illustrated in Figure 1. In a schematic form, the sequence of accounts can be described as follows: the product and income accounts are basically devoted to real or non-financial economic activity in the current period. The product account primarily records gross value added for particular sectors, while the income account is devoted to ways of income distribution and redistribution through transfers. In essence, the product can be used either on consumption or savings. What remains after consumption is evidenced in the so-called accumulation accounts formed by capital and financial accounts. The savings provide resources for non-financial investments measured in the capital account. When there is a difference between savings and capital formation for a particular sector, then this sector has formed either savings or dissavings. This is monitored in the capital account in the form of net lending or net borrowing, respectively. With non-financial lending and borrowing, there emerges by 
definition also their financial equivalents, which are recorded in financial accounts either as the acquisition of financial assets or the incurrence of liabilities by a particular sector in gross as well as net forms.

Figure 1. National account matrix with balance sheets and accounts

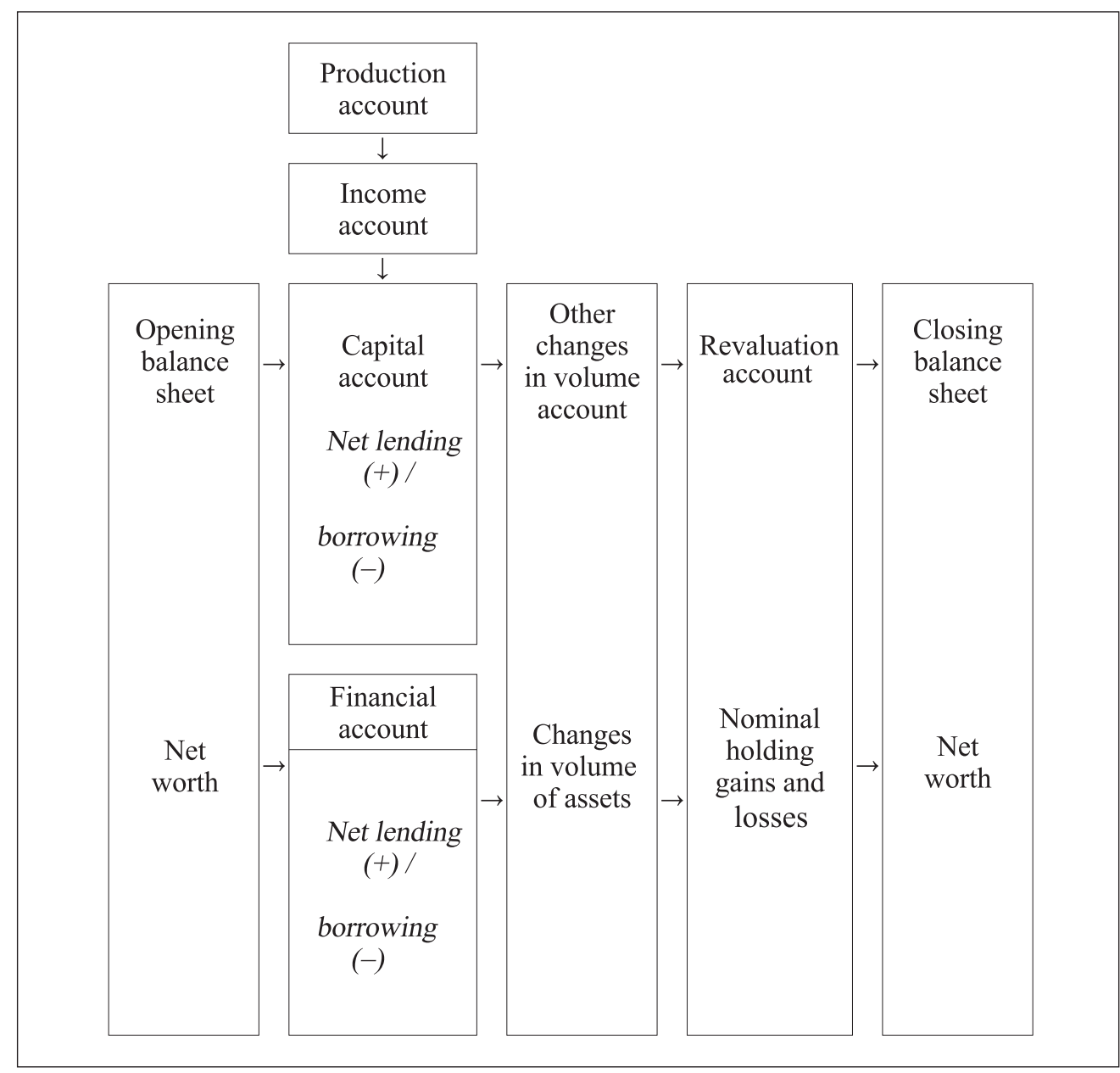

(Source) Eurostat (2013) 
The financial balance sheets, as well as the corresponding transaction accounts, are commonly published in a matrix form in which sectors are in columns and instruments or transactions are in rows. Each intersecting cell then shows purchases or sales of a financial instrument by a sector at a particular time or during the given period. The columns and rows can be added up. The sums of the rows are zero, since net purchases of assets must equal net sales or net liabilities. The sum of a column provides a sector's surplus or deficit, that is, its net acquisition of financial assets or net incurrence of liabilities. This vertical summation provides an immediate link to national income accounts via the capital account, where net lending / net borrowing is by definition the same amount. Let us emphasize that the relationship between financial and capital accounts provides an important link between financial and real economic variables. For further details, see for example Lequiller and Blades (2014).

Financial accounts provide the bulk of data utilizable for many research questions in this field. Massaro (2012) argued that the incentive to establish a financial accounts agenda is intimately connected to opinions about the importance of finance to real economic processes. The practical introduction, development, and data collection required has been mostly done by national central banks in cooperation with national statistical offices; see Bonis and Gigliobianco (2012).

Financial accounts data are currently collected by many countries under the unifying methodology consisting of the United Nations' System of National Accounts 2008, also known as SNA 2008, which provides a globally recognized accounting framework for the collection of national accounts data. Under their financial subsection provide rules for the composition of institutional sectors and specify requirements for the valuation of financial instruments. They also require financial accounts to be maintained in accordance with the principle of double-entry bookkeeping and quadruple-entry bookkeeping. European countries make use of a compatible methodology called the European System of Accounts 2010, or ESA 2010, which, however, includes additional details. ${ }^{1}$

\footnotetext{
${ }^{1}$ In the USA, the integration of National Income and Product Accounts (NIPA) together with flow of funds accounts are provided by the socalled Integrated Macroeconomic Accounts; see Yamashita (2013) for details.
} 


\section{Euro Area ImBalances}

The accounting approach has been widely used in recent years to analyze the macroeconomic imbalances that lay behind the financial crisis, in the euro area (ECB 2011) as well as in other countries, for example Godley (1999b) for the USA. This research recognized that credit and debt relations matter and that it is important for the various economic sectors to pay attention to their financial positions and particularly to the sustainability of their debt levels. Although most attention in the literature has been paid to public finances, analyses grounded in financial accounts showed that private debt was a source of instability in the recent crisis. Furthermore, the financial position of government and private sector is influenced also by the financial position of the whole national economy in relation to the rest of the world. Therefore, for purposes of financial stability, it is important to pay attention not only to government finances, but also to private and foreign financial positions. This view was recently integrated into the implementation of the Macroeconomic Imbalance Procedure in the EU; see Cuerpo and Hobza (2014).

The accounting framework nicely illustrates that financial relations among institutional sectors are mutually interdependent. For example, in a two-sector economy consisting of the domestic economy and the rest of the world, the net financial assets of one country are represented by net financial liabilities of the others. If we break the economy down into three sectors, the complexity increases; however, the sum of financial wealth must, by definition, be zero. If one sector of the economy is in surplus, financial logic holds that there must be at least one sector in deficit.

This provides interesting and important theoretical as well as policy implications that are, however, not generally recognized. For example, a government budget deficit is always accompanied by a surplus either in the private sector or in the foreign sector. Consequently, this implies that every government deficit covered by issued bonds adds financial wealth to the private sector or to the foreign sector - see Wray (2012a). This is a rarely mentioned supplement to the analysis provided by loanable fund theory, in which budget deficits diminish national savings. From this perspective, budget deficits reduce loanable funds on the one hand, but increase the financial wealth of the private sector on the other.

In policy discussions following the euro area sovereign debt crisis, there was a real emphasis on austerity in government finances. However, in a closed economy, as 
emphasized by Forstater and Murray (2013), budget deficits are the only way in which the private sector can save and accumulate net financial wealth. Thus, government debt is crucial to households and firms, because it provides finance for their financial savings, or for money to spend (understood as the liability of the central bank) that they would not have otherwise. The growth of government debt adds to money stocks and increases money flows, while debt contraction usually subtracts from money flows. As Nikiforos and Zezza (2017) noted, if for some reason future tax payers have to pay for government debt, they will also earn the proceeds of these payments, under the assumption that the debt is not held by foreigners. Koo (2013) argued that government debt reduction is problematic for an economy that has balance sheet recession, that is, when the private sector tries to repay its debt, since it could prolong the recession. In similar fashion, Tichy (2013) questioned the consequences of debt reduction resulting from the Treaty on Stability, Coordination, and Governance in the Economic and Monetary Union, also dubbed the Fiscal Compact.

Tichy (2013) and Nieuwenhuyze (2013) emphasized that the euro area crisis was not caused by insufficient government budget discipline, but rather by developments in the financial positions of households and non-financial corporations that fuelled the upward as well as the downward development of aggregate demand. Both of these authors also point to imbalances in the balance of payments in the intra-euro area, where there were remarkable differences between the so-called surplus countries of the core and deficit countries in the periphery. The euro area's overall position has roughly balanced the claims that the surplus countries hold over the deficit countries. Fernándéz and Garciá (2017) provide complementary detail showing that short-term capital inflows from the rest of the world occur to core countries, where local microfinance institutions intermediate these inflows to the periphery; so that part of the financial boom in Spain was ultimately fuelled by savings from outside the euro area.

Let us illustrate these sectoral balances and their interdependencies on concrete countries. Figure 2 and Figure 3 show the development in the net financial position for the private sector, government, and rest of the world. To express the net financial wealth of individual sectors, we use the balancing item of the capital account called net lending / net borrowing (code B.9, according to ESA 2010). When the net financial position is positive, this item refers to net lending; thus, the sector has the availability to finance other sectors. When the net financial position is negative, this item refers to net borrowing and consequently corresponds to the situation in which the sector is obliged to borrow from others. The sum of net lending / net borrowing across all sectors (including 
the rest of the world) must be nil, as the net lending / net borrowing of the total economy must match the net borrowing / net lending of the rest of the world. Therefore, the figures form a mirror image.

Figure 2 focuses on Germany, traditionally an exporting country, where continuing private sector surpluses have been allowed through the accumulation of financial wealth against the foreign sector. In this situation, the public sector does not need to create budget deficits in order to ensure that the private sector does not lower its financial wealth or even go into debt.

Figure 2. The net financial positions: Germany

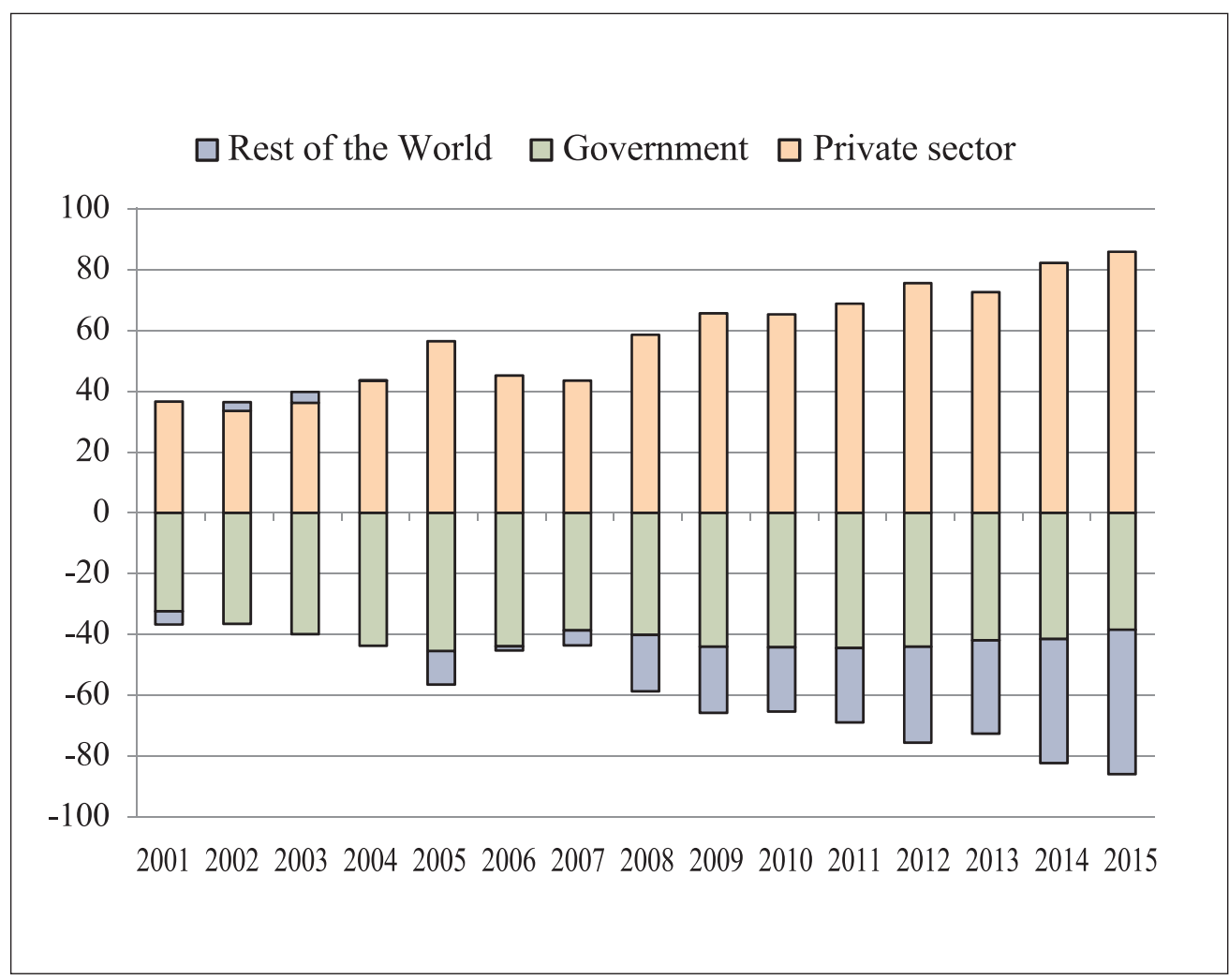

(Source) Author's calculations, using data available from Eurostat, European Sector Accounts Database. 
Figure 3 depicts the situation of Spain, a country in the euro area periphery that was severely hit by the financial crisis. The clear difference is that Spain has been recording a negative current account and hence was issuing financial debts to remunerate importers. This means that at least one domestic sector must have its net financial balance negative. In the case of Spain, the financial accounts reveal a negative balance for the private sector, while the public sector was rather fiscally prudent before 2008.

We do not want to raise a polemic about the quality of government investment as to whether its debt provides a productive or an unproductive utilization of real funds.

Figure 3. The net financial positions: Spain

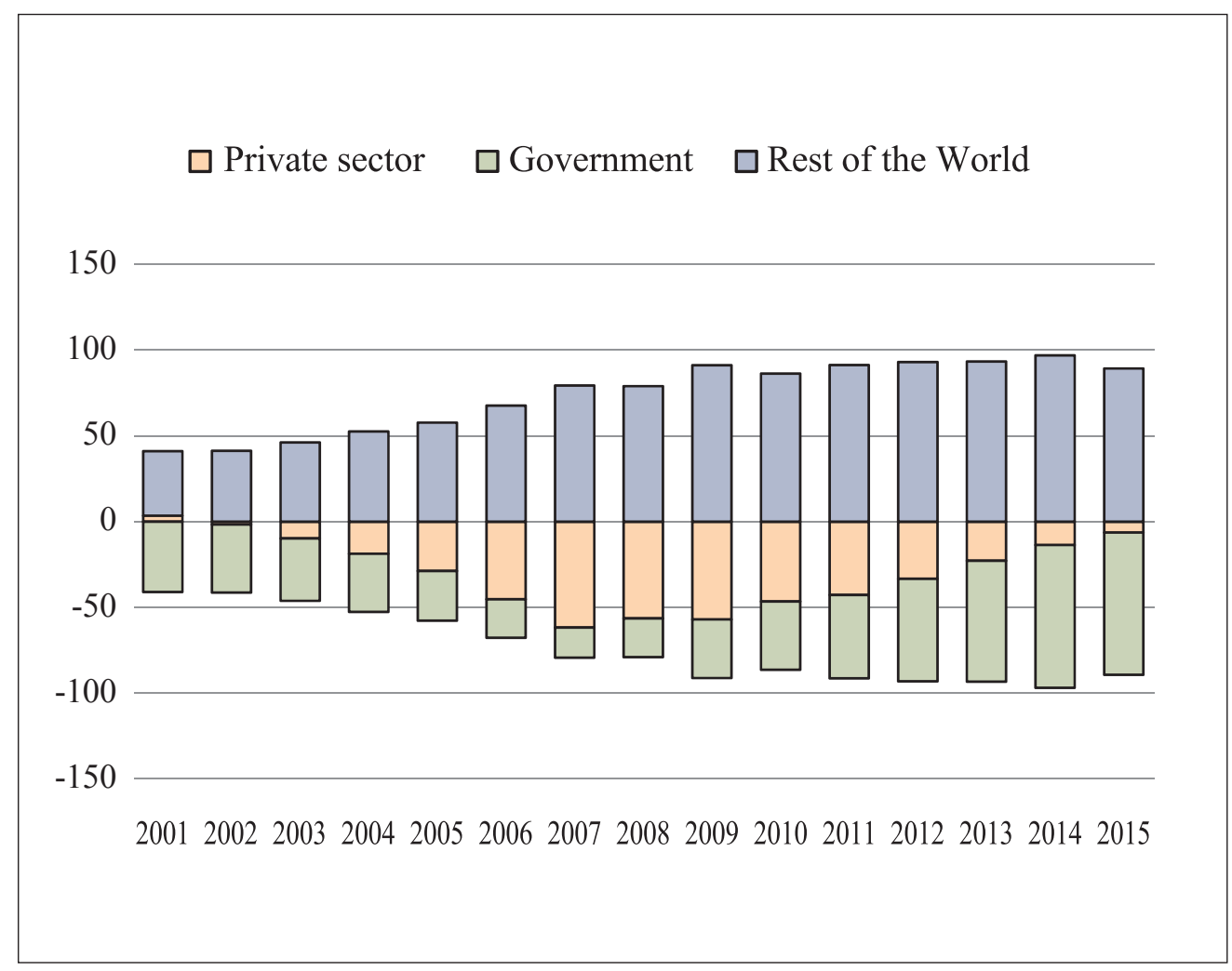

(Source) Author's calculations, using data available from Eurostat, European Sector Accounts Database. 
Similarly to any other intertemporal intermediation, what the value of government debt will be in the future naturally depends on its uses. For stabilization policies, Leijonhufvud (1998) makes an interesting point, arguing that around the 1970s, there was an important shift in the macroeconomic policy literature. Before this period, macro policy had automatically been thought of as stabilization policy, since markets were considered unstable and subject to waves of optimism and pessimism, while government was a source of stability. In the 1970s, the optimism about government and pessimism about the private sector turned into diametric opposites. The recent euro area crisis acted as a reminder that for financial and economic stability, both the private and the public sector had to pay attention to their financial positions, as well as to their whole economic engagement with the rest of the world, and particularly needed to consider the quality and sustainability of their debt levels.

Although the three-sector perspective presented above may look simple, it provides valuable insights into the financial health of a particular economy and the sustainability of individual sectors' balance sheets. In this respect, three-sector balances served as an accessible theory used by financial journalism, as reported by Wolf $(2011,2012)$, or in major banks' reports (Weisenthal 2012).

The further elaboration of the three-sector perspective can provide useful implications for the question of financial stability. Financial crisis occurs when the present value of financial assets faces questions that surface when either the value of the assets is expected to fall or their debt to income ratio becomes too high and is perceived as unsustainable. Investors can then lose confidence, suddenly stopping their financing and requiring the return of their resources. Since uses are commonly allocated for longer periods, this process can imply fire sales, falls in asset prices, or the spread of the contagion into the wider economy. This scenario means that the negative net lending of a particular sector increases its debt to income ratio. As shown in Figure 3, Spanish households run large deficits, driven particularly by mortgages that fuel local housing bubbles, which in turn lead to the increasing indebtedness of that sector. When the rise in indebtedness continues for a longer period, the sector could turn originally sound hedge finance into speculative financing. It is Ponzi financing, following the terminology of Minsky (2008), where borrowing is not used to repay original debt, but to roll over existing debts, or to pay only for the debt service.

Therefore, the sectoral balances show how important it is to integrate financial flows into economic analyses, since in modern economies, the real and financial sectors are heavily interdependent. 


\section{Stock-Flow Consistent Models}

The accounting approach represents a different way to mainstream methods of modeling the economy, and particularly its wealth, debt, and credit flows. The mainstream equilibrium models are based on assumptions that neglect the role of money and finance. Therefore, their essence and comparative advantage is in the modeling of a barter economy, where the focus is on the real sector and relative prices. In contrast, the accounting approach refers to monetary considerations in which money and finance are not separated from the real economy, and which allow the study of their mutual interactions. One important implication is that the analysis is in nominal terms. In this respect, the accounting approach does not find its roots in Walrasian analysis or the work of neoclassical authors, but in the tradition of authors such as John Law, Richard Cantillon, Thomas Tooke, John Stewart Mill, and who all emphasise monetary flows in their theories, as does Menšík (2014). The accounting approach provides challenging views on economic phenomena and puzzling economic questions. Bezemer (2016) provides a deep overview of these issues.

The accounting approach divides the economy into individual sectors and shows the interactions of each sector. Contrary to equilibrium models, these sectoral accounting models are characterized by a separate capturing of all flows of funds and all stocks and their circulation within the economy.

One important line of accounting models represents SFC models. SFC modeling is a macroeconomic approach that models all stocks and flows of funds within the economy. The background of these models consists of two main components, which are an accounting framework and behavioral equations. The accounting framework corresponds in its principles with the logic of the construction of the system of national accounts. The framework uses balance sheets to record the stocks of particular sectors, as well as a set of transaction matrices to depict the transactions and the capital gains of each institutional sector of the economy. The accounting framework is in principle a matter of pure logic, since it is built upon a set of logical relations. For example, every instance of spending corresponds to someone's income, thus the aggregate spending is always equal to the aggregate income; or that every liability is someone else's asset, which implies that financial assets have to equal liabilities. This is informative about relations, but not about causation, however. Causal explanations are provided by the behavioral component, which utilizes economic theory to stipulate causal connections 
among individual components of the accounting framework.

Since SFC models are closely related to SNA, their origin goes hand in hand with their development. Their roots are generally recognized in the work of Morris A. Copeland, who introduced a concept of the flow of funds in a national accounting perspective. His aim in Copeland (1949) was to answer fundamental economic questions like "When total purchases of our national product increase, where does the money come from to finance them?" and consequently, "When purchases of our national product decline, what becomes of the money that is not spent?" To answer these questions, he introduced a new approach to the integration of real side and financial side of the economy consisting of the quadruple-entry system.

In connection with Copeland's work, Nobel laureate Richard Stone came up with a concept known as standard national accounting. This concept was later broadly elaborated by James Tobin and consequently by Wayne Godley. Tobin (1982) first defined the components of the stock flow approach. In his Nobel lecture, Tobin proposed five defining features that meaningful macroeconomic models should fulfill. According to his work, it is appropriate for such models to cover: (1) precision regarding time, (2) tracking of stocks, (3) several assets and rates of return, (4) modeling of financial and monetary policy operations, and finally (5) Walras's Law and evaluating constraints.

The main proponent and creator of SFC models was Wynne Godley. Godley, with his colleagues from the New Cambridge School, started developing models that integrated stocks and flows. He successfully demonstrated the existence of an organized framework according to Tobin's theoretical foundations; see Godley and Cripps (1983), Godley and Zezza (1989), and Godley (1996, 1997, 1999a).

Currently, SFC models are mainly developed in the USA and Europe. The main research focused on the modeling of the financial sector and financialization, income distribution issues, and open economies issues. It especially to euro area, but also to the international monetary system. Many papers tailoring these types of models to specific conditions have been published. For example Ryoo (2010) incorporates a continuous time and medium- to long-run analysis into above-mentioned approaches. Recent additions by Lavoie and Zhao (2010) and Lavoie and Daigle (2011) emphasize the path dependency of the Godley and Lavoie model and thus highlight the evolutionary character of SFC modelling. Kinsella and Khalil (2011) modeled debt deflation in small open economies. Recently, these models have also found interdisciplinary applications in the area of physics, when modeling the influence of economic activities involving heat emissions (Berg et al. 2015). For a detailed overview of recent research, see Caverzassi and Godin 
(2015) and Nikiforos and Zezza (2017).

The SFC model of the economy is built as a set of sectors interconnecting with each other via individual balance sheets. The division of the economy into these sectors is usually in accord with the division provided by the SNA, but can also be redefined according to research questions. For example, for the purpose of analyzing the effects of income distribution, the household sector could be sub-sectored into specific percentiles according to wealth. The main advantage of the SFC model is the possibility of integrating the real and the financial side of the economy. Hence, the accounting framework can illustrate a complex of relations among sectors and thus demonstrate sources of portfolio choices, consumption and investment decisions, and financing in one model.

So far we have focused particularly on accounting frameworks. However, the behavioral component is of equal importance, as it gives the models concerns, essentially the presuppositions about causalities and the division of variables between exogenous and endogenous factors. In this respect, SFC models are prominently developed in the post-Keynesian tradition. It is worth noting that this is not a necessary characteristic and the accounting framework can potentially be supplemented by other economic theories. However, post Keynesians originated and developed these models, as they facilitated the post-Keynesian analysis with their distinctive emphasis on money, with its endogeneity and fundamental uncertainties. As shown by Dos Santos (2006), the SFC models are able to unify the economic theories of different Keynesian and post-Keynesian authors such as P. Davidson, W. Godley, H. Minsky, and J. Tobin. The models capture the monetary characteristics of economies that evolved in a historical time when the expectations of agents were expressed by past decisions. The possibility of tracking the direction and intensity of flows between sectors makes this approach appropriate for the analysis of various monetary theories like the Financial Instability Hypothesis as proposed by Minsky (1992), or the Modern Monetary Theory put forward by Wray (2012b).

Contrary to mainstream models, SFC models are characterized by omitting the assumptions of representing agents' maximizing their utility, rational expectations, and utility functions. Post-Keynesian SFC models usually suppose the following propositions: firms borrow funds in order to finance inventories and investment is financed through retained profits. Households borrow money to consume and invest in long-term assets or in firms' bonds. Central banks set the interest rate to achieve desired liquidity and government with its central bank ensures the institutional environment by interacting with all participants within the system. 
The accounting framework together with behavioral equations permits the economy to be modeled, as well as its steady state to be solved; and consequently allows the behavior of the entire system to be simulated through behavioral equations. SFC models result in analytical and numerical solutions of the steady state, under conditions that set numerical values to parameters and exogenous variables of the model. Hence, making changes in the values of parameters or exogenous variables enables comparative dynamics to be performed to see how a model economy reacts to these changes. It is worth mentioning that problems with SFC models may occur due to mathematical complexity in pursuit of a realistic description of the economy. In such a complex situation, as Dos Santos and Macedo e Silva (2009) argued, a model intuition is vague and unclear and model solutions are therefore not easy to interpret.

As an advantage of SFC, models can be considered a possibility of incorporating an agent's expectations in line with post-Keynesian theory of fundamental uncertainty and path dependency. The agent's norms and targets are taken from past performance and create future expectations; these expectations change surpluses or shortages of stocks (in forms of inventories, money balances, or wealth) in the next period. Thus, this mechanism ensures feedback from an agent's behavior in response to structural changes within the model; see Caverzasi and Godin (2015).

\section{SFC Model of the Three-Sector Economy}

Let us illustrate the principles of SFC modeling on a concrete example of a threesector economy as stylized above. In respect to ESA 2010, the model consists of a domestic private sector, represented by households including non-profit institutions serving households (S.14, S.15); and by non-financial (S.11) and financial sectors without a central bank (S.12 without S.121). The domestic public sector is formed by the government (S.13) together with the central bank (S.121) and the foreign sector covers the rest of the world (S.2).

We construct the model to be meaningful, but the main criterion is its capability to demonstrate the fundamental principles of SFC modeling. In this respect, there are some important simplifications of the model economy in favor of clarity and comprehension. We assume a pure labor economy producing only non-durable consumption goods and 
services and where the entire production is consumed in the same period. However, if any sector consumes amounts that are different to its resources, the difference is recorded in its net financial position. This means that we utilize only current and financial accounts, and not capital accounts. Therefore, the net worth of any sector consists only of its net financial wealth.

Although the main focus is on the net financial positions as treated by interrelations among sectors, there are other simplifying assumptions. For example, wages and prices are not modeled and also inflation is omitted. Exchange rates and interest rates are also ignored. This implies that we do not have to deal with capital gains and revaluation effects in our model. Firms are pure production units held by households and therefore do not hold any assets. We also ignored the intermediary financial role of commercial banks that is commonly encompassed by standard SFC models.

In our model economy, money is issued by a domestic central bank and is held by households only. Bonds are issued by government and held by the central bank, households, and the foreign sector. Foreign reserves are issued by the foreign sector and held by the central bank. To tackle these simplifications would unnecessarily increase the complexity of the model. That said, the reader can find inspiration in dealing with them particularly in Godley and Lavoie (2007a).

To present the accounting model, it is typical to construct a balance sheet and a Transactions Flow Matrix (TFM), which is followed by the mathematical expression of the behavioral relations between the model variables. For our purposes, we provide only the theoretical model without calibration or estimations of the parameters against empirical data.

First, there is the balance sheet matrix, which records stocks of assets and liabilities on an aggregate level. In general, the balance sheet presents the sum of particular accounting items across individual sectors at specific points in time, based on an allocation of assets and liabilities within the economy. Similarly to balance sheets in the SNA, the model balance sheet gives us a view of assets and liabilities located in an individual sector made at a specific point in time and also shows interconnections among the sectors. This framework helps us to understand the financial structure of the model economy. Note the convention that a stock of assets is entered with a plus sign and a stock of liabilities is entered with a minus sign.

The balance sheet of our model economy is captured in Table 1. The columns are divided into three sectors, where the domestic private sector is further subdivided into households and firms and the public sector into government and central bank. The first 
three rows represent the allocation of a stock within the economy for each sector. The last row shows the aggregate net worth of the economy for each sector.

Table 1. Balance sheet of simple three-sector model

\begin{tabular}{|l|c|c|c|c|c|c|}
\hline Balance sheet matrix & \multicolumn{2}{|c|}{ Domestic Private Sector } & \multicolumn{2}{|c|}{ Domestic Public Sector } & Foreign Sector & \\
\hline & Households & Firms & Government & $\begin{array}{c}\text { Central } \\
\text { Bank }\end{array}$ & Rest of World & $\sum$ \\
\hline Stock of Money & $+M$ & & & $-\mathrm{M}$ & & 0 \\
\hline Bonds & $+B_{h}$ & & $-B_{g}$ & $+B_{c b}$ & $+B_{R o W}$ & 0 \\
\hline Foreign reserves (FX) & & & $-\mathrm{FX}$ & $-F X$ & 0 \\
\hline $\begin{array}{l}\text { Net worth } \\
\text { (Total debt/wealth) }\end{array}$ & $-V_{h}$ & $-V_{g}$ & $-V_{\text {Row }}$ & 0 \\
\hline \multicolumn{1}{c|}{} & 0 & 0 & 0 & 0 \\
\hline
\end{tabular}

(Source) Author's construction.

The balance sheet can be read as follows: the central bank issues money $M$ that is held by households. This means that money is not only an asset, but also represents a liability for the central bank. Households can choose whether to allocate their total wealth $V_{h}$ into money or bonds $B$. We assume that households can not go into debt, i.e., they fund the purchase of financial assets only from their own non-financial resources, which are always positive. Their total wealth is the result of accumulated savings from previous periods. However, since there are no capital assets, the total wealth is equal to the financial net worth (BF.90 in ESA codes). Although its value is positive for the domestic private sector, it is entered with a minus sign in order to ensure that the sum over all rows is zero. Bonds are issued by the domestic government (denoted by the subscript $B g$ ) to finance its expenditure during the current period. Since bonds are not liquid, the central bank as the bank of the government buys and converts them into money. The central bank also intermediates the transactions between the domestic economy and the rest of the world by buying foreign bonds, representing foreign reserves $F X$. The government sector's net worth $V_{g}$ is given by the difference between the foreign reserves and bonds held by the central bank and the liabilities issued in form of bonds and money by the 
government and central bank. The public sector's net worth can be negative or positive depending on the amount of accumulated foreign reserves as against issued bonds. The rest of the world balance contains foreign reserves and domestic bonds and its net worth is determined by the difference between these two.

The second step is to construct a TFM that captures changes in real and financial interactions in motion in the economy over specific period. The TFM is depicted in the form of a table that enables the recording of financial flows among different sectors in a unified framework. It consists of various kinds of transactions, passing among institutional sectors, which are divided according to uses and resources.

The logic of the construction of the TFM corresponds with the flow components of national accounts. The matrix connects initial and final balance sheets in a way that ensures consistency of the whole model. The columns are formed by same sectors as in the balance sheet matrix. What is different is the meaning of the rows, which are devoted to various types of transactions realized among sectors in a certain period. The rows of the TFM can also be read as markets in which the sectors captured in the columns interact.

The layout also corresponds to standard national accounts statements when it proceeds from the current accounts to accumulation accounts. The top half of the TFM is basically a summation of all product and income statements, while the bottom half is devoted to capital and financial accounts showing the implications of transactions. The important property of the TFM is that it reflects the flows (changes in the stocks) for each transaction that results between interacting institutional units. An outcome of the TFM is a set of behavioral equations that arises from each interaction. The behavioral equations allow us to precisely calculate the consequences of changes made in the model system.

The TFM relevant to our model is provided in Table 2. It demonstrates standard macroeconomic flows. The first row concerns consumption $C$, which represents the use of funds by households and of resources by firms. Similarly, government expenditure $G$ is a source of income for firms. The resources for government are taxes $T$ that are levied on households. The fourth and fifth lines capture international trade relations, i.e., exports $E X$ and imports $I M$ of non-durable goods and services. If we sum up the first five rows for firms, we get the aggregate expenditure received by this sector, which is equivalent to the gross domestic product $Y$. Since the firms are held by households, this product may be understood as their income or resource, which is allocated either to current consumption and taxes or between money and bonds. This means that the savings of the private sector are represented by claims on the domestic public sector. The 
evidence in the bottom half of the table is devoted to financial relations. The penultimate item records foreign reserves $F X$, which are a corollary to exports and imports. Since we assume that the transactions between households and rest of world are intermediated by the central bank, the foreign reserves are accumulated as against the issuance of money. Conversely, if net exports are negative, the central bank contracts liquidity from households and provides domestic bonds to foreigners.

Consequently, the matrix has three important properties. At first, each sector has resources and consumptions; thus, each column provides the budget constraints of the sector. As a result, the sum of any column must equal to nil, to ensure that all funds that a sector receives are accounted for. This is expressed by the last row by the total debt or wealth (accumulated net worth). Second and consequently, each row must also sum to zero, to ensure that each market clears. That implies that the supply of a particular asset

Table 2. Transactions flow matrix

\begin{tabular}{|c|c|c|c|c|c|c|}
\hline $\begin{array}{l}\text { Transactions } \\
\text { Flow Matrix }\end{array}$ & $\begin{array}{r}\text { Domestic } \\
\text { Sect }\end{array}$ & ivate & $\begin{array}{r}\text { Domestic } \\
\text { Sect }\end{array}$ & Public & $\begin{array}{l}\text { Foreign } \\
\text { Sector }\end{array}$ & \\
\hline & Households & Firms & Government & $\begin{array}{c}\text { Centra } \\
\text { Bank }\end{array}$ & $\begin{array}{l}\text { Rest of } \\
\text { World }\end{array}$ & $\sum$ \\
\hline Consumption & $-C$ & $+C$ & & & & 0 \\
\hline Taxes & $-T$ & & $+T$ & & & 0 \\
\hline Government expenditure & & $+G$ & $-G$ & & & 0 \\
\hline Imports & & $-I M$ & & & $+E X$ & 0 \\
\hline Exports & & $+E X$ & & & $-I M$ & 0 \\
\hline Production & {$[+Y]$} & {$[-Y]$} & & & & 0 \\
\hline Change in Stock of Money & $-\Delta M$ & & & $+\Delta M$ & & 0 \\
\hline Change in Bonds & $-\Delta B_{h}$ & & $+\Delta B_{g}$ & $-\Delta B_{c b}$ & $-\Delta B_{R o W}$ & 0 \\
\hline Change in Foreign reserves & & & & $-\triangle F X$ & $+\Delta F X$ & 0 \\
\hline$\sum$ & 0 & & 0 & & 0 & 0 \\
\hline
\end{tabular}

(Source): Author's construction. 
is matched by purchases of that asset and ensures that no funds go astray; see Barwell and Burrows (2011). This is captured by zeros in the last columns of the table. Note that this could be different if we change our assumptions and enable savings of nonfinancial assets to be accumulated. In this case there will be a positive value for capital in a particular column such as the real estate of households. The third property, which is not discussed here, is that the interactions generate market prices, which together with revaluations, determine the nominal values of particular items. Let us note for completeness that a minus sign in the TFM is associated with an outgoing flow or use of funds and a positive sign is associated with an incoming flow or resources.

\section{A. Mathematical expression of the three sector model}

The three-sector model introduced above is considered to be elementary, but of sufficient complexity to be able to illustrate the most fundamental principles of SFC models. It consists of several endogenous variables, that is, gross domestic product $Y$, disposable income $Y_{d}$, consumption $C$, household wealth $V_{h}$ and its distribution, taxes $T$, fiscal stance $(T-G)$, money $M$, bonds $B$, foreign reserves $F X$, and imports $I M$. Note that since there are no real assets, the household wealth is here represented by the household's financial net worth. This is the balance of the household's financial balance sheet, i.e., total financial assets minus total liabilities, recorded at current market values. In contrast, exogenous variables are government expenditures $G$, tax rates $\theta$, export $E X$, import propensities $\mu$, propensities to consume out of regular income $\alpha_{1}$, and out of wealth $\alpha_{2}{ }^{2}$

The fundamental equations of the simple three-sector model can be expressed by mathematical derivations taken from the TFM, namely from the production side of the economy; thus, from firms in the domestic private sector,

$$
Y=C+C+(E X-I M)
$$

where $Y$ is gross domestic product generated by firms, $C$ is consumption spending, $G$ is government spending, $E X$ is exports, and $I M$ is imports (so $E X-I M=$ net exports).

\footnotetext{
${ }^{2}$ We assume in line with post-Keynesian theory that the money supply is endogenously rather than exogenously determined. Money supply endogeneity implies that central banks do not exogenously determine the quantity of money supply, but they can control the interest rate exogenously.
} 
Domestic income $Y$ is identical to personal income $Y p$, since there are no capital gains and revaluation effects, thus $Y p=Y$.

Disposable income $Y_{d}$ of households is equal to national income $Y$ less paid taxes,

$$
Y_{d}=Y(1-\theta)
$$

where $\theta$ is the tax rate on (taxable) income.

The consumption function is defined as,

$$
C=\alpha_{1} Y_{d}+\alpha_{2} V_{h-1} \quad 0<\alpha_{2}<\alpha_{1}<1
$$

where consumption is determined by propensities to consume from disposable income $\alpha_{1}$ and from wealth from previous periods $\alpha_{2}$.

Consequently, it is necessary to define households' wealth $V_{h}$. Wealth is a lagged stock variable and therefore it is an essential dynamic component between consequent periods of our three-sector model:

$$
V_{h}=Y_{d}-T-C
$$

The wealth variable can be rewritten as a savings function,

$$
V_{h}=\alpha_{2}\left(\alpha_{3} Y_{d}(1-\theta)+V_{h-1}\right) \quad \alpha_{3}=\left(1-\alpha_{1}\right) / \alpha_{2}
$$

where $\alpha_{3}$ is the household's implicit target of wealth from disposable income.

Taxes $T$ are interpreted as a proportion of nominal income:

$$
T=\theta Y
$$

The variables government expenditure $G$ and exports $E X$ are exogenous, in contrast to imports $(I M)$. Imports are endogenous and are defined as the propensity to import a fraction $\mu$ from the national income.

From an accounting perspective, we may say that the production side Equation (1) of

$$
I M=\mu Y
$$


the national income $Y$ must be equal to its uses, Equation (4),

$$
C+G+(E X-I M)=Y=C+T+V_{h}
$$

By arranging Equation (8) and substituting variables from Equation (3), Equation (4), Equation (5), Equation (6), and Equation (7), we can rewrite the national income $Y$ as follows:

$$
Y=\left(G+E X+\alpha_{2} V_{h-1}\right) /\left[1-\alpha_{1}((1-\theta)+\mu)\right]
$$

From this point, we can calculate the steady state solution for wealth, $V_{h}^{*}$.

$$
V_{h-1}^{*}=\alpha_{2}\left(\alpha_{3} Y_{d}(1-\theta)+V_{h-1}\right) \quad \alpha_{3}=\left(1-\alpha_{1}\right) / \alpha_{2}
$$

The steady state value of wealth is equal to nil, or $V^{*}=0$, in the sense that the target wealth to disposable income ratio $\alpha_{3}$ has been fulfilled. This means that in the steady state there is no need for savings and all national income is spent on consumption and taxes.

Lastly, we can compute the steady state value for income $Y^{*}$, in cases when exports are equal to imports and where is no accumulated wealth, and we thus get:

$$
Y^{*}=(G+E X) /(\theta+\mu)
$$

From the steady state equation, we can infer that national income in our model depends only on government spending and exports and also on the tax rate and the propensity to import.

For completeness, we need to cover all the variables, therefore we also define the financial side of three-sector model, that is money stock $M$, bonds $B$, and foreign reserves $F X$.

Money stock is defined as demand for money based on accumulated wealth minus demand for bonds,

$$
M_{d}=V_{h}-B_{d}
$$

where $M_{d}$ is demand for money and $B_{d}$ is demand for holding bonds by households. 
The demand for holding bonds is calculated in an analogous way, as the difference between the money supply and foreign reserve holdings.

$$
B_{d}=M_{S}-F X
$$

Consequently, a stock of foreign reserves is viewed as the difference between imports and exports.

$$
F X=E X-I M
$$

The result of government debt management is expressed by the supply of bonds $B S$.

$$
B_{S}=G-T
$$

In order to ensure that Equation (12), Equation (13), Equation (14), and Equation (15) hold, the demand and supply of money and bonds must be always equal.

$$
\begin{aligned}
M_{d} & =M_{S} \\
B_{d} & =B_{S}
\end{aligned}
$$

According to the previous equations, we obtain the following from the transaction flow matrix:

$$
+\Delta V-\Delta B-\Delta F X=0
$$

and hence by arranging the variables and substituting $\Delta V-\Delta(M+B)=S-I$, we substitute for private sector investment in a way that allows us to convert this expression into familiar sectoral balance accounting relations.

$$
(S-I)+(T-G)+(I M+E X)=0
$$

Notice that Equation (18) and Equation (19) will have the same numerical values, since they refer to financial and current accounts, respectively.

In the literature, it is more usual to find Equation (19) written in the form:

$$
(S-I)=(G-T)+(E X-I M)
$$


This final equation is a well-known accounting identity for the three-sector balances. Equation (20) describes the balance between accounting identities when net financial saving of private sector $(S-I)$ is equal to the public sector borrowing requirement $(G-$ $T)$ plus the current account balance $(E X-I M)$.

As explained above, the differences in sectoral positions are equal to changes in their financial wealth. In our model, the concrete distribution of financial wealth among sectors mainly depends on the government decision to consume and tax, on exports, on propensities to import and to consume out of income, and on previous wealth.

It would go beyond the scope of the paper to simulate the model and provide impulse responses. The model is, however, constructed in a way that it captures changes induced in the entire system when one of the parameters is modified by a change in the behavior of any of the sectors involved in the model. This allows the model to reflect fiscal or monetary policy implications.

In this sense, Barwell and Burrows (2011) produced a Bank of England financial stability paper dealing with balance sheets at the time of the Great Moderation. They find that balance sheet fragility is strongly linked to overall financial instability, which has not been revealed in other models of the Bank of England before. Their paper points out links between the macroeconomic variables and the development of the balance sheet.

In respect of macroprudential policy and financial stability, our illustrative model can provide some general policy implications. It illustrates how balance sheets of individual sectors are mutually interdependent. While there was a major emphasis on debt levels for individual member governments before the euro area crisis, the immediate recommendation of our model is that other sectors' debt to income ratios are also crucial and need to be monitored and eventually restricted. Under such a stabilization policy, it is important to take care of measures such as the Loan To Income (LTI) ratio for households or the Loan To Value (LTV) ratio for mortgage lending, in order to prevent speculative and even Ponzi financing and consequent economic bubbles. Moreover, many other financial crises have shown that rising foreign indebtedness, either of the private sector or the government, could cause large disturbances.

Building a more complex model by adding more sectors or instruments could naturally provide more specific results and policy implications. In the case of the euro area crisis, we refer the reader to an interesting and accurate paper by Godley and Lavoie (2007), who foresee the shortcomings of the euro area integration and conclude that the system will only work if the European central bank provides support for weak euro countries. 
By changing the representation of sectors or instruments and the accounting and behavioral relations among them, SFC models allow for the provision of various policy scenarios and show that debt sustainability and financial stability depend on the way the economic system is integrated, that is, on the balance sheet compositions of individual agents and their behavioral options. Further elaboration of the SFC model in the euro area could thus contribute, for example, to the question of the sustainability of government financing of euro area member states and standalone countries, as discussed by Gros (2013) or as econometrically tested by De Grauwe and Yuemei (2013).

\section{Conclusions}

In this paper, we focus on the accounting approach to macroeconomic modeling that has risen in popularity after the great financial crisis that brought macroeconomic difficulties to many developed countries. We examine the main features and advantages of accounting models that allow the possibility to interconnect the real and financial sides of the economy in a coherent and unified framework. This is their important advantage over classical mainstream models. Furthermore, we introduce the SNA and the financial accounts that form its subpart. After the great financial crisis there have been worldwide policy initiatives to fill the data gaps for specific financial sectors and instruments.

Our main objective was to introduce SFC modeling, which represents the most developed branch of accounting models, and show their connection with the SNA and especially with financial accounts, in order to show the link between these two and how the SNA can provide data for such models. For this purpose, we give an overview of the euro area financial crisis provided by the three-sector perspective, dividing the economy into the domestic private sector, government, and the foreign sector, and examine their main balance sheet items and interrelations. This three-sector perspective allows us to present the fundamental principles and possibilities of the SFC models in a context relevant to the real world.

We have built a simplified SFC model of an open economy consisting of three sectors, where individual sectors interact in their economic activity with the ensuing financial implications. The model is designed to demonstrate the main features of SFC modeling, formed by balance sheet and transaction flow matrixes and behavioral equations, as 
well as their relations to the SNA and financial accounts (ESA 2010). Furthermore, these three-sector balances are one of the main building blocks of SFC modeling that provides the link interconnecting real and financial variables.

Although the model contains only three sectors and three financial instruments, it allows us to draw some general policy conclusions, especially concerning macroprudential policy and financial stability.

Our model illustrates how balance sheets of the individual sectors are mutually interdependent, and that financial stability should not only take into account the debt to income ratio of those government sectors, but also the debt to income ratio of the private sector, as well as the overall indebtedness of the domestic economy towards nonresidents. Rising debt to income ratios could lead to speculative and even Ponzi financing and, conseguently, to economic bubbles with their destabilizing effects. This dynamic can be identified on the euro area periphery.

During recent years, SFC models have risen highly in popularity and many research topics have been opened, mostly concerning questions of financial crises, income distributions, open economies, and the international monetary order. The methodology of these models is quite flexible in being able to specify any number of sectors or instruments according to the particular research question. In relation to the euro area, a further study could focus on the question of introduction of the euro currency in other European Union countries, especially in small open economies, and how this would change their fiscal policy options.

Received 16 June 2017, Revised 17 July 2017, Accepted 10 August 2017 


\section{References}

Barwell, Richard, and Burrows, Oliver. "Growing Fragilities Balance Sheets in the Great Moderation". Bank of England Financial Stability Paper No. 10 (2011). http:// www.bankofengland.co.uk/financialstability/Documents/fpc/fspapers/fs_paper10.pdf

Bê Duc, Louis, and Le Breton, Gwenaël. "Flow-of-funds Analysis at the ECB: Framework and Applications". European Central Bank Occasional Paper no. 105. (2009). https://www.ecb.europa.eu/pub/pdf/scpops/ecbocp105.pdf

Berg, Matthew, Harley, Brian, and Richters, Oliver. "A Stock-flow Consistent Inputoutput Model with Applications to Energy Price Shocks, Interest Rates, and Heat Emissions". New Journal of Physics (2015): 1-21.

Bernardo, Javier Lopez, and Wildauer, Rafael. "US Economy: Flying with one engine". Kingston Financial Balances Model, Macroeconomic Outlook Issue 1 (2016). http://business.kingston.ac.uk/sites/default/files/KFBM-MacroeconomicOutlook-Issue-1-Feb-2016.pdf

Bezemer, Dirk J. "Understanding financial crisis through accounting models". Accounting Organizations and Society 35 (2010): 676-88.

Bezemer, Dirk J. "Towards an 'accounting view' on money, banking and the macroeconomy: history, empirics, theory". Cambridge Journal of Economics 40 (2016): 1275-95.

Blankenburg, Stephanie, King, Lawrence, Konzelmann, Sue, and Wilkinson, Frank. Cambridge Journal of Economics 37 (2013): 463-77

De Bonis, Riccardo, and Gigliobianco, Alfredo. "The Origins of Financial Accounts in the United States and Italy: Copeland, Baffi and the Institutions" in The Financial Systems of Industrial Countries edited by Riccardo De Bonis and Alberto Pozzolo, Springer-Verlag Berlin Heidelberg, 2012.

Borio, Claudio. "The financial cycle and macroeconomics: What have we learnt?". Journal of Banking \& Finance 45 (2014): 182-98. 
Burgess, Stephen, Burrows, Oliver, Godin, Antoine., Kinsella, Stephen, and Millard, Stephen. "A dynamic model of financial balances for the United Kingdom". Bank of England, Staff Working Paper No. 614 (2016). http://www.bankofengland.co.uk/ research/Documents/workingpapers/2016/swp614.pdf

Caiani, Alessandro, Godin, Antoine, Caverzasi, Eugenio, Gallegati, Mauro, Kinsella, Stephen, and Stiglitz, Joseph E. "Agent based-stock flow consistent macroeconomics: Towards a benchmark model". Journal of Economic Dynamics \& Control (2016): $375-408$.

Caverzasi, Eugenio, and Godin, Antoine. "Post-Keynesian stock-flow-consistent modelling: a survey". Cambridge Journal of Economics, Oxford University Press 39, 1 (2015): 157-87.

Cesaratto, Sergio. "Alternative interpretations of a stateless currency crisis". Cambridge Journal of Economics 41 (2017): 977-98.

Copeland, Morris Albert. "Social Accounting for Money flows". The Accounting Review 24 (1949): 254-64.

Cuerpo, Carlos, and Hobza, Alexandr. "The Surveillance of Macroeconomic Imbalances in the EU: The Sectoral Perspective" in A Flow-of-Funds Perspective on the Financial Crisis, Volume II edited by Winkler, Bernhard, van Riet, Ad, and Bull, Peter: Macroeconomic Imbalances and Risks to Financial Stability. Palgrave Macmillan Studies in Economics and Banking. Springer, 2014.

De Grauwe, Paul. "Design Failures in the Eurozone: Can They Be Fixed? LEQS Papers 57 (2013). http://www.lse.ac.uk/europeanInstitute/LEQS\%20Discussion\%20 Paper\%20Series/LEQSPaper57.pdf

De Grauwe, Paul, and Yuemei, Ji. "Self-fulfilling crises in the Eurozone: An empirical test", Journal of International Money and Finance 34 (2013): 15-36.

Dos Santos, Claudio H., "Keynesian Theorising during Hard Times: Stock-Flow Consistent Models as an Unexplored 'Frontier' of Keynesian Macroeconomics". Cambridge Journal of Economics 30 (2006): 541-65. 
Dos Santos, Claudio H., Antonio, and Macedo E Silva, Antonio, Carlos. "Revisiting (and Connecting) Marglin-Bhaduri and Minsky: An SFC Look at Financialization and Profit-led Growth". Levy Economics Institute Working Paper 567, 2009. http://www. levyinstitute.org/publications/revisiting-and-connecting-marglin-bhaduri-and-minsky

European Central Bank. "The Financial Crisis in the Light of the Euro Area Accounts: a flow-of-Funds perspective". European Central Bank, Monthly bulletin (2011): 99-120. https://www.ecb.europa.eu/pub/pdf/other/art3_mb201110en_pp99-120en. pdf?2908233ef6ef0e1951006bc25d9bfbld

Eurostat. "European system of accounts (ESA 2010)", Publication Office of the European Union. (2013). http://ec.europa.eu/eurostat/data/database

Eurostat. "G20 Data Gaps Initiative (DGI) - background" Publication Office of the European Union. (2015). http://ec.europa.eu/eurostat/statistics-explained/index.php/ G20

Eurostat, 2016a. "Manual on Government Deficit and Debt - Implementation of ESA 2010 (2016 edition)". Publication Office of the European Union. (2016) http:// ec.europa.eu/eurostat/web/products-manuals-and-guidelines/-/KS-GQ-16-001

Eurostat, 2016b. "European Sector Accounts Database Statistics". Publication Office of the European Union. (2016) http://ec.europa.eu/eurostat/web/sector-accounts/data/ database.

Forstater, Mathew, and Murray, Michael J. The Job Guarantee: Toward True Full Employment (London: Palgrave Macmillan, 2012).

Fernández, Rafael, and Garciá, Clara. "Wheels within wheels within wheels: the importance of capital inflows in the origin of the Spanish financial crisis", Cambridge Journal of Economics (2017).

Godley, Wynne. "Money, Finance, and National Income Determination.” Levy Economics Institute Working Paper 167 (1996). http://www.levyinstitute.org/ publications/money-finance-and-national-income-determination

Godley, Wynne, 1997. "Macroeconomics without Equilibrium or Disequilibrium.” 
Levy Economics Institute Working Paper 205. (1997). http://www.levyinstitute.org/ publications/macroeconomics-without-equilibrium-or-disequilibrium

Godley, Wynne, 1999a. “Open Economy Macroeconomics Using Models of Closed Systems." Levy Economics Institute Working Paper 285. (1999). http://www. levyinstitute.org/publications/open-economy-macroeconomics-using-models-ofclosed-systems

Godley, Wynne, 1999b. "Seven Unsustainable Processes: Medium-Term Prospects and Policies for the United States and the World." Levy Economics Institute, Strategic Analysis. (1999). http://www.levyinstitute.org/publications/seven-unsustainableprocesses

Godley, Wynn, and Cripps, Francis. Macroeconomics. (Oxford: Oxford University Press, 1983).

Godley, Wynne, and Lavoie, Marc. "Simple Open Economy Macro With Comprehensive Accounting: A Two Country Model", Centre for Financial Analysis \& Policy, Cambridge (2005).

Godley, Wynne, and Lavoie, Marc. 2007a. Monetary Economics: An Integrated Approach to Credit, Money, Income, Production and Wealth (New York: Palgrave MacMillan, 2007).

Godley, Wynne, and Lavoie, Marc. 2007b. "Fiscal Policy in a Stock-Flow Consistent (SFC) Model". Journal of Post Keynesian Economics (2007).

Godley Wynne, and Lavoie, Marc, 2007c. "A simple model of three economies with two currencies: the eurozone and the USA", Cambridge Journal of Economics, 31, 1 (2007): 1-23.

Godley, Wynne, and Zezza, Gennaro. “A Simple Real Stock Flow Monetary Model of the Italian Economy". In The Stock-flow Consistent Approach: Selected Writings of Wynne Godley, edited by Lavoie Mark and Zezza Gennaro. (2012). (Palgrave Macmillan, 1986.)

Gros, Daniel. "Foreign debt versus domestic debt in the euro area". Oxford Review of 
Economic Policy, 29, 3 (2013): 502-17.

Kinsella, Stephen, and Khalil, Saed. "Debt-Deflation in a Stock-Flow Consistent Macromodel". In Contributions in Stock-Flow Consistent Modeling: Essays in Honor of Wynne Godley, edited by Papadimitriou, Dimitri. B. and Zezza, Gennaro. (Palgrave Macmillan, 2011)

Koo, Richard, C. "Balance Sheet Recession as the Other-half of Macroeconomics", European Journal of Economic and Economic Policies 10 (2013): 136-57.

Lavoie, Mark, and Daigle, Gauthier. "A Behavioural Finance Model of Exchange Rate Expectations within a Stock-Flow Consistent Framework". Metroeconomica 62, (2011): 434-58.

Lavoie, Mark, and Zhao, Jun. "A Study of the Diversification of China's Foreign Reserves within a Three-Country Stock-Flow Consistent Model". Metroeconomica 61, (2010): 558-92.

Le Heron, Edwin. "Monetary and Fiscal Policies in a Post Keynesian StockFlow Consistent Model". In Keynes and Macroeconomics after 70 Years: Critical Assessments of the General Theory, edited by Wray, Randal, L. and Forstater, Mark. (2009). (Edward Elgar Publishing, 2008).

Leijonhufvud, Axel. "Two types of crisis", Zagreb Journal of Economics 2. (1998): $39-54$

Lequiller, Francois, and Blades, Derek. Understanding National Accounts: Second Edition. (OECD Publishing, 2014).

Massaro, Riccardo. "Private Sector Debt Matters Too: Theoretical Perspectives on Credit and the Building of Financial Accounts". In The Financial Systems of Industrial Countries, edited by De Bonis, Riccardo and Pozzolo, Alberto. (Berlin, Heidelberg: Springer-Verlag, 2012).

Menšík, Josef. "The Origins of the Income Theory of Money", Review of Economic Perspectives 14, 4 (2014). 
Minsky, Hyman, Philip. “The Financial Instability Hypothesis”, Levy Economics Institute Working Paper 74. (1992). http://www.levy.org/pubs/wp74.pdf

Minsky, Hyman, Philip. Stabilizing an Unstable Economy. (New York: McGraw-Hill, 2008).

Mitchell, William, Muysken Joan, and Van Veen Tom. Growth and cohesion in the European Union: The Impact of Macroeconomic Policy. (Cheltenham: Edward Elgar Publishing, 2006).

Mitchel, William, and Wray, Randall, L. "Modern Monetary Theory and Practice". The Centre of Full Employment and Equity. (2014).

Murray, Michael J. and Forstater, Mathew. Employment Guarantee Schemes: Job Creation and Policy in Developing Countries and Emerging Markets. (New York: Palgrave Macmillan, 2013).

Nieuwenhuyze, Christophe, Van. "Debt, assets and imbalances in the euro area. An aggregate view'. Revue de l'OFCE 127 (2013): 123-52.

Nikiforos, Michalis, Zezza, Grennara. "Stock-flow Consistent Macroekonomic Models: A Survey", Levy Institute Working Paper No. 891. http://www.levyinstitute. org/pubs/wp_891.pdf

Reichlin, Lucrezia. "Monetary Policy and Banks in the Euro Area: The Tale of Two Crises". Journal of Macroeconomics 39 (2014): 387-400.

Ryoo, Soon. "Long Waves and Short Cycles in a Model of Endogenous Financial Fragility". Journal of Economic Behavior \& Organization 74 (2010): 163-186.

Tichy, Gunther. "What Can Sector Accounts Tell About the Financial Crisis?" Intereconomics 2 (2013).

Tobin, James. Money and Finance in the Macroeconomic Process. Journal of Money, Credit and Banking 14 (1982): 171-204.

United Nations. "Financial Production, Flows and Stocks in the System of National Accounts", The United Nations Publications, (2015). 
Yamashita, Takashi. "A Guide to the Integrated Macroeconomic Accounts". Survey of Current Business (2013): 12-27.

Weisenthal, Joe. Goldman's Top Economist Explains The World's Most Important Chart, And His Big Call For The US Economy, Last modified December 10, 2012 http://www.businessinsider.com/goldmans-jan-hatzius-on-sectoral-balances-2012-12

Winkler, Bernard, van Riet, Ad, and Bull, Peter. 2014a. “A Flow-of-Funds Perspective on the Financial Crisis Volume I: Money, Credit and Sectoral Balance Sheets". (New York: Palgrave Macmillan, 2014).

Winkler, Bernard, van Riet, Ad, and Bull, Peter. 2014b. "A Flow-of-Funds Perspective on the Financial Crisis, Volume II: Macroeconomic Imbalances and Risks to Financial Stability”. (New York: Palgrave Macmillan, 2014).

Winkler, Bernard. "Cross-checking and the flow of funds". In Enhancing Monetary Analysis, edited by Papademos, Lucas, and Stark, Jürgen . (2010).

Wolf, Martin. "Understanding sectoral balances for the UK", Financial Times blog released on December 05, 2011, http://blogs.ft.com/martin-wolf-exchange/2011/12/05/ understanding-sectoral-balances-for-the-uk/

Wolf, Martin. "The balance sheet recession in the US", Financial Times blog, released Jul 19 2012, http://blogs.ft.com/martin-wolf-exchange/2012/07/19/the-balance-sheetrecession-in-the-us/

Wray, Randall, L. "Modern Money”. Levy Economics Institute Working Paper 252, (1998). http://www.levyinstitute.org/publications/modern-money

Wray, Randall, L. 2012a. "Imbalances? What Imbalances? A Dissenting View." Levy Economics Institute Working Paper 704, (2012). http://www.levyinstitute.org/pubs/ wp_704.pdf

Wray, Randall, L. 2012b. "Modern Money Theory: A Primer on Macroeconomics for Sovereign Monetary Systems”. (New York: Palgrave Macmillan, 2012). 